\title{
On the Innovation Ability of College Students under the Multi Factor Control
}

\author{
Limin $\mathrm{Ma}^{1,{ }^{*}}$, Qian Zhang ${ }^{2}$ \\ ${ }^{1}$ Department of Electrical Engineering, North China Electric Power University, Baoding, China. \\ ${ }^{2}$ Students'Affairs Division, North China Electric Power University, Baoding, China \\ *corresponding author
}

Keywords: College student, Innovation ability, Ability training

\begin{abstract}
With the development of today's society, more and more attention has been paid to the innovation ability, and the recruitment of some enterprises will be the choice for the university students whether they have the ability to innovate. At present, the innovation ability of college students is gradually paid attention to by the society, through some practical examples and some statistical data found that many factors will restrict the development of College students. In this paper, we discuss the factors that restrict the innovation ability of college students, and give some suggestions on the innovation ability of college students.
\end{abstract}

\section{Introduction}

The 21st century is the era of knowledge-based economy, knowledge economy is an era of continuous innovation and creation, want to develop in the economic society, we need to continuously improve the ability to innovate [1]. With the continuous strengthening of competition among countries around the world, the role of innovation in the role of the month to play an important role, especially in developed countries, has been positioned as a national strategic innovation measures. To strengthen the country's ability to innovate, we need to strengthen the cultivation of innovative talents. Contemporary college students are the reserve force of the national innovation talent, is to strengthen the force of national innovation ability. College Students' innovation ability will directly affect the development of the country's future innovation ability and the important power to promote social progress and scientific and technological ability.

In recent years, China has gradually begun to pay attention to the innovation ability of university students, and increase the intensity of training innovative talents. Although China has made some achievements in cultivating innovative college students, but the national comprehensive university, is still a lack of systematic training of students' innovation ability, the innovation ability of college students how to behave and how to evaluate the students' innovative ability "and" what are the factors restricting the innovation ability of university students "problems there is no unified view, there is no unified method of cultivating students' innovative ability from what. Therefore, this article embarks from the university student's innovation ability, discusses the factor which restricts the university student "s innovation ability, and has given the corresponding suggestion to these factors.

\section{Research Status Analysis}

Different countries for the cultivation of innovative ability is not the same, through the analysis of various countries for the cultivation of innovative ability, the main list of several different countries for the cultivation of innovative ability. American education sector has great enthusiasm for innovation, some scientists through the organization of some activities to help students develop innovative ability [2]. Some colleges and universities gradually carry out innovative ability card law courses, training and education of College Students' innovation ability, and the combination of extracurricular experiments and classroom teaching, to create a good environment for innovation. At the same time, many enterprises also provide a good internship environment for college students, 
so that students will be their own subject and the practice of enterprises to combine the training of innovative ability [3].

Japan's education sector for the students' innovative ability is more characteristic, it is mainly through the development of innovative ability courses to train students' innovative ability. As a required course for each student, the innovation project can make the students choose the subject of their own interest to create, and to show the creative works to encourage the spirit of innovation. At the same time, in the teaching method, pay attention to the flexible education, emphasize the innovative thinking [4].

China also attaches great importance to innovative thinking. A lot of experts and scholars in our country have discussed the innovation ability of university students. ZouGuangping (2010) [5] et al. Through the research and analysis of the current university education, the course construction as the basis for college students to improve innovation ability, the establishment of innovative curriculum system. At the same time, many colleges and universities will be undergraduate tutor production as the concept of running a school. Undergraduate tutorial system mainly refers to the part of the undergraduate students are equipped with a mentor, so that undergraduates participate in the topic of tutor, in order to cultivate the innovation ability of undergraduates.

Culture of different countries of the world are on the innovation ability of students in different directions, some of the students' creative ability through childhood training, some innovative ability through government policy to support the school, some students participate in the innovation of the thesis, in cultivating students' innovative ability. In a word, all countries attach great importance to the innovation ability of college students. However, due to the influence of the traditional concept and the population base, the innovation ability of college students in our country is restricted by many aspects, so that the innovation ability of college students can not be significantly improved.

\section{Restricting the Analysis of the Factors of College Students' Innovation Ability}

Through the analysis of the current college students' innovation ability and the innovation literature, the evaluation system of College Students' innovation ability is constructed. According to the evaluation system of College Students' innovation ability, the innovation ability of college students is analyzed, and some factors which restrict the innovation ability of university students are analyzed.

According to the research of a certain university, tit is concluded that some factors which restrict the innovation ability of college students [6]:

The Number of College Students is too much, the School Resource Allocation is Insufficient. With the background of economic globalization not only development, in order to be able to integrate with the international education, some domestic universities began to expand enrollment, the university has become a popular education, it will continue to increase the number of College students. As the number of college students increases, the amount of funds allocated for education is limited, the limited funds are limited, the existing resources of universities and the number of students can not meet the growing number of college students. Most of the University's funding for student schools, libraries, teaching buildings, canteen and other infrastructure, but these funds for a steady stream of college students is not enough. Therefore, the university education resources can not be guaranteed, resulting in the majority of college students do not have a good university education. Many college teachers nervous, a teacher to teach courses, no time for students to carry out the cultivation of innovative ability. Therefore, the number of college students is too much, the school resource allocation problem is one of the factors that affect the innovation ability of College students.

The Lack of Teaching Concept. Because of the large population of our country, the university education is gradually popular, so many private universities in China have established the trend. However, this still can not solve the problem of college students, so many universities have opened a large class, the number of courses in about 100 people. A small number of courses also have about 30 people, only the number of students in the course of the study is small. This has led to the teacher can not be each student is concerned, can only rely on the usual lessons to meet the needs of 
the course. In this case, the teacher's training for students' innovative ability is almost zero. At the same time, because the school no more resources for teachers' creative ability training, so after a long time of accumulation, resulting in school teaching is the usual teaching knowledge to students, the school teaching concept has become oriented to impart knowledge, without considering the students' innovation ability. Therefore, the teaching concept of the school is also one of the factors that affect the innovation of college students.

Lack of Innovation System. Although some colleges and universities are more attention to the innovation ability of university students, but lack of appropriate training system. The implementation and practice of the training system of innovative education must start from the cultivation of innovation ability, innovation education is mainly embodied in a specific project, innovation system must meet the requirements of students' innovation ability, in the current university innovation system, and did not reflect the students' innovation ability based innovation system.

The Mode of Industrial Cooperation and Innovation does not Form a Cooperative Force. Research cooperation mode has been promoted in many universities, mainly through the cooperation between schools and enterprises, the students will be put into the enterprise to study and research, increase the students' innovation ability. However, the mode of production and research cooperation has not reached the expected goal. The main problems are: Although the cooperation between enterprises and schools, but their goals are different, resulting in no increase in students' innovation ability. The main goal of the enterprise is by working with the school to provide the knowledge base by the school, combined with their own economic base, and ultimately achieve the purpose of enterprise development, and the goal of the school is through the enterprise strong financial strength, cultivate students' innovation ability, finally students innovative achievements can be used enterprise. Based on the different purposes, enterprises eager to benefit, and college students' innovation is not innovation can whenever and wherever possible, but through a series of accumulation, finally can draw the innovative achievements, and in this process, enterprises also need to bear the ultimate risk of innovation cannot be applied in enterprises; followed by the enterprises and schools cooperation, students in the enterprise is not a long time, so you can not contact the enterprise innovation department, is responsible for the work of ordinary enterprises, so the students to participate in the cooperation enthusiasm is not high.

The Factors of Students themselves. According to the college students' innovation system, it is found that the factors of college students themselves are one of the main factors that restrict their ability to innovate [7]. Mainly in: first of all, the independent innovation awareness of college students is not strong enough. The normal university students are the beginning of a small rise early, then increased after admitted to the university entrance examination, so in this process, as long as the stable through primary school, middle school and high school to enter the University, you only need to follow the teacher to explain the knowledge can be admitted to the University to study, in this environment, the independent innovation consciousness of college students is not strong. In the ordinary college students, are still under the influence of high school education. As long as learning knowledge of the teacher teach, graduate can, in this case to improve students' innovative ability is very difficult; secondly, the knowledge innovation of college students seriously affected the students' innovative ability.

\section{The Cultivation of College Students' Innovation Ability}

After the research on the innovation system of university students and the research on the practical innovation ability of college students, some suggestions on how to cultivate the innovation ability of college students are given through the combination of reference and actual life:

The Rational Allocation of School Resources, Change the Concept of School Education. The school plays a very important role in the construction of the current college students' creative ability. Schools in the allocation of resources, the need for reasonable allocation of resources according to the current number of college students, not all of the resources are put into the basic construction of College students. Based on the construction of college students is important, but not for the great 
help to improve students' innovative ability, so the school should assign a fixed proportion of resources to cultivate college students' innovative ability, only cultivate the innovation ability of college students is a session or sessions, it can be very good to promote other students' innovative ability. Secondly, schools need to change the concept of teaching. Schools should be clear, college students by the high school after college entrance examination in the coming in, so the general college students do not have the ability to innovate. Therefore, in the curriculum design, we need to take into account how to cultivate the innovative ability of college students, the creation of innovative ability courses, the introduction of innovative teachers.

The Reasonable Construction of College Students' innovation System. Innovation is a thing in the days and months multiplying accumulated knowledge, and can innovate through observing the things, so in the University, the school should guide students to build a reasonable system of innovation, innovation is not to inform the students lying in bed can do, need to go through the system of knowledge learning can. At the same time, the school needs innovation of college students to reward, reward the good innovation ability of college students, to ensure that in the later time can help other students build the innovation system and maintain a good ability to innovate.

To Set up a Reasonable Innovation Platform. Schools should be based on the innovative ability of students, to build a reasonable innovation platform. Mainly include: the establishment of simulation laboratory. The school according to the actual situation, the purchase of related software, so that teachers in the process of daily teaching, reasonable use of simulation software, and increase the practical thinking ability of students, training students' innovative thinking; school organization innovation project. The school organized some innovative subject, and give support in funding and personnel, by the students under the guidance of the teacher, to study the subject of innovation; the school should often organize some innovation competition activities, to promote college students' innovation, promote the innovation consciousness of students, and students the innovation ability as the basis of teachers' performance evaluation, the ability to innovate better students, should be rewarded.

To Improve the Quality of College Students. Schools should make strict rules and regulations to ensure that college students in the comprehensive development of the university. A healthy development of college students, through daily activities and good rest time, can make the mind to keep awake, in addition with the continuous accumulation of knowledge, will make their own ability to innovate continuously enhanced.

\section{Conclusion}

This paper discusses the cultivation of College Students' innovative ability, and according to the investigation of College Students' innovation ability in daily life, some factors restrict the development of college students, and according to the students' innovation ability system, some influence on College Students' innovative ability were analyzed. Finally, some suggestions are given for the innovation ability of college students.

\section{Acknowledgements}

This research is supported by the teaching reform project of North China Electric Power University.

\section{Reference}

[1] Qinling Dong, Liu Kangwei. Innovative education of college students and teaching reform in Colleges and universities [J].Science Education Forum, 2005 (18)

[2] Yu Wenzhao, Liu Jianrong. Innovation and creativity: the development and cultivation of [M]. Dalian: Dongbei University of Finance and Economics press, 2008

[3] CaiKeyong, Zhang Xiumei. Knowledge economy and education innovation [J]. Beijing: China Economic Publishing House, 1999 
[4] Lee Jingshan Hill. On College Students' innovative ability training [D].Northeast Normal University, 2003

[5] Zou Guangping, Xia Xing. A study on the cultivation mode of College Students' innovative ability [J]. Heilongjiang higher education.2010.03.05

[6] Cao Yingyi. Research on the construction of the index system of College Students' innovation ability.2008.5 Wuhan University of Technology [D].

[7] Su Yu Rong. Study on the cultivation mode of College Students' innovation ability [D]. Wuhan University of Technology.2013.5 